\title{
Analysis of Early Phase HIV-1 Replication and Integration Events by Using Real-time PCR
}

Laura Graf ${ }^{1}$, Steven P. Moran ${ }^{1}$, Sally Ro ${ }^{1}$, Carlos M. C. de Noronha ${ }^{2}$ and Binshan Shi ${ }^{1}$ *

${ }^{1}$ Department of Basic and Clinical Sciences, Albany College of Pharmacy and Health Sciences, Albany, New York, USA; ${ }^{2}$ Department of Immunology and Microbial Disease, Albany Medical College, Albany, New York, United States of America

*For correspondence: Binshan.shi@acphs.edu

\begin{abstract}
[Abstract] Upon entry into a host cell, the HIV-1 virus undergoes a series of critical early replication events including reverse transcription, nuclear import, and integration of its cDNA into the host genome. Molecular assays used to detect and analyze changes in HIV-1 early phase replication events are valuable tools in developing potential antiretroviral drugs, as well as studying the pathogenesis of HIV. Described here are the molecular assays utilized to detect and quantify HIV-1 early, intermediate, and late reverse transcription (RT) products. In addition to this, protocols for quantifying HIV-1 2-LTR circle DNA and proviral DNA after integration are also included. In these protocols, the optimized TaqMan Real-time PCR reagent is used to increase assay sensitivity and reproducibility. Furthermore, a nested PCR is applied to HIV-1 integration quantification with increased accuracy.
\end{abstract}

Keywords: HIV-1, Reverse transcription, 2-LTR cycle DNA, Integration, Real-time PCR

[Background] After binding to the receptor and fusing to the host cell's lipid bilayers, the HIV-1 nucleoprotein complex first enters the cytoplasm, crosses the nuclear envelope, and finally integrates the reverse-transcribed HIV genome into that of the host cell. During this early phase of replication, HIV1 converts its single-stranded RNA genome into linear double-stranded DNA in cytoplasm by an intricate reverse transcription process (Hu and Hughes, 2012). After nuclear import, some of these linear viral genomes are integrated into the host chromatin. These are termed proviruses. The remaining cDNA that fails to integrate is circularized into either 1-LTR circle DNA or 2-LTR circle DNAs (Sloan and Wainberg, 2011). HIV-1 can counteract various host restriction factors that can interfere with its early phase replication events (Zheng et al., 2012). Molecular assays used to detect and analyze changes in HIV-1 early phase replication events are valuable tools in studying HIV pathogenesis and in developing potential antiretroviral drugs. We report here methods to quantitatively analyze several critical events during HIV-1 early phase replication by using Real-time PCR. The early, intermediate and late stages of reverse transcription events are represented by the initiation of HIV-1 minus strand DNA synthesis, the elongation of minus-strand DNA synthesis following transfer of minus strand DNA, and the synthesis of complete double-stranded linear viral DNA after plus-strand DNA transfer respectively. Given that 2-LTR circles are exclusively found in the cell nucleus, they have become a useful marker of viral nuclear import (Sloan and Wainberg, 2011). As shown in Figure 1, a nested PCR is utilized to quantify HIV-1 integration with increased sensitivity and specificity. Since Alu sequences are the most abundant repetitive DNA, containing over one million copies dispersed throughout the human genome, the $1^{\text {st }}$ 
round of PCR is designed to amplify a fragment between the integrated HIV-1 gag gene and the host genomic Alu sequence element. Both forward and reverse Alu PCR primers are used in $1^{\text {st }}$ round Alugag PCR, since either orientation of Alu sequence can exist in human genome. To avoid the amplification

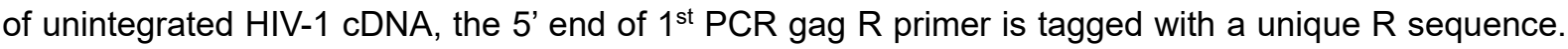
Only the $1^{\text {st }}$ round PCR amplicons containing the $R$ sequence can be used as templates in the $2^{\text {nd }}$ round of Real-time PCR. The optimized TaqMan Real-time PCR reagent is used to increase assay sensitivity and reproducibility. All PCR primers, probe sequences, and their amplicon locations are listed in Table 1.

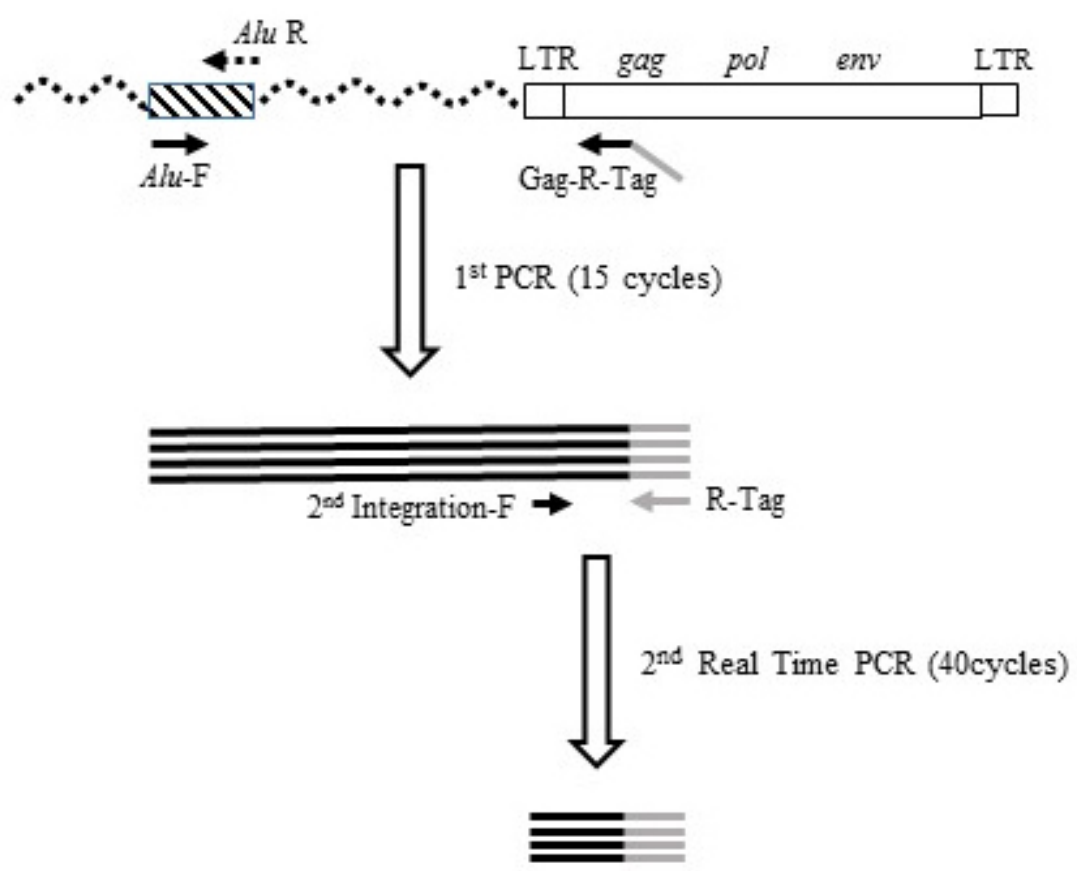

Figure 1. A nested PCR for quantification of HIV-1 integration 
Please cite this article as: Graf et. al., (2019). Analysis of Early Phase HIV-1 Replication and Integration Events by Using Real-time PCR,Bio-protocol 9

Table 1. A list of sequences of PCR primers and probes

\begin{tabular}{|c|c|c|}
\hline Primer/Probe & Sequence $\left(5^{\prime} \rightarrow 3^{\prime}\right)$ & Target \\
\hline Early RT-F & GCCTCAATAAAGCTTGCCTTGA & HIV-1 RU5 \\
\hline Early RT-R & TGACTAAAAGGGTCTGAGGGATCT & HIV-1 RU5 \\
\hline Early RT probe & FAM-AGAGTCACACAACAGACGGGCACACACTA-TAMRA & \\
\hline Intermediate RT-F & CTAGAACGATTCGCAGTTAATCCT & HIV-1 gag \\
\hline Intermediate RT-R & CTATCCTTTGATGCACACAATAGAG & HIV-1 gag \\
\hline Intermediate RT probe & FAM-CATCAGAAGGCTGTAGACAAATACTGGGA- TAMRA & \\
\hline Late RT-F & TGTGTGCCCGTCTGTTGTGT & HIV1 U5 PBS \\
\hline Late RT-R & GAGTCCTGCGTCGAGAGATC & HIV1 U5 PBS \\
\hline Late RT probe & FAM-CAGTGGCGCCCGAACAGGGA-TAMRA & \\
\hline 2-LTR-F & TGGTTAGACCAGATCTGAGCCT & HIV-1 R-U3 \\
\hline 2-LTR-R & AGGTAGCCTTGTGTGTGGTAGATCC & HIV-1 R-U3 \\
\hline 2-LTR probe & FAM-TAGTGTGTGCCCGTCTGTTGTGTGAC-TAMRA & \\
\hline GAPDH-F & GCATGGCCTTCCGTGTCCCC & GAPDH \\
\hline GAPDH-R & CCCTCCGACGCCTGCTTCAC & GAPDH \\
\hline GAPDH probe & GGTGGACCTGACCTGCCGTCTAGA & \\
\hline $1^{\text {st }}$ Integration Alu-F & AGCCTCCCGAGTAGCTGGGA & Alu - gag \\
\hline $1^{\text {st }}$ Integration. Alu-R & TTACAGGCATGAGCCACCG & Alu - gag \\
\hline $\begin{array}{l}1^{\text {st }} \text { Integration. Gag-R- } \\
\text { Tag }\end{array}$ & CAATATCATACGCCGAGAGTGCGCGCTTCAGCAAG & Alu - gag \\
\hline $2^{\text {nd }}$ Integration-F & AACTAGGGAACCCACTGCTTAAG & HIV-1 R - gag \\
\hline $2^{\text {nd }}$ Integration-R-Tag & CAATATCATACGCCGAGAGTGC & HIV-1 R - gag \\
\hline $2^{\text {nd }}$ Integration probe & FAM- TAGTGTGTGCCCGTCTGTTGTGTGAC- TAMRA & \\
\hline
\end{tabular}

\section{Materials and Reagents}

1. Axygen ${ }^{\circledR}$ MicroVolume Extended-Length Filtered Pipet Tips (Axygen, catalog number: TXLF10)

2. Axygen $^{\circledR}$ Universal Fit $100 \mu$ l Filtered Pipet Tips (Axygen, catalog number: TF100RS)

3. Axygen $^{\circledast}$ Universal Fit $200 \mu$ Filtered Pipet Tips (Axygen, catalog number: TF200RS)

4. Axygen ${ }^{\circledR}$ Universal Fit $1,000 \mu$ l Filtered Pipet Tips (Axygen, catalog number: TF1000LRS)

5. Axygen $1.5 \mathrm{ml}$ Snaplock Microtubes (Axygen, catalog number: MCT150CS)

6. $10 \mathrm{~cm}$ cell culture dish (Celltreat, catalog number: 229621)

7. 24-well plate (Celltreat, catalog number: 229123)

8. MicroAmp Fast Optical 96-well Reaction Plate (Thermo Fisher, catalog number: 4346907) 
9. MicroAmp Optical Adhesive Film (Thermo Fisher, catalog number: 4311971)

10. $0.45-\mu \mathrm{m}$-pore-size filters (Thermo Fisher, catalog number: EMD Millipore ${ }^{\mathrm{TM}}$ SLHV033RS)

11. Ach2 cells (NIH AIDS Reagent Program, catalog number: 349)

12. HEK-293 Cells (NIH AIDS Reagent Program, catalog number: 103)

13. Opti-MEM ${ }^{\mathrm{TM}}$ (Thermo Fisher, catalog number: 31985062)

14. X-tremeGENE 9 DNA Transfection Reagent (Sigma, catalog number: 6365779001)

15. The vesicular stomatitis virus $G$ protein (VSV-G) expression vector pVSV-G (Clontech Laboratories, catalog number: 631530)

16. HIV-1 plasmids pNL4-3 env(-)nef(-)gfp(+) (a gift from Dr. Vicente Planelles)

17. DNeasy Blood \& Tissue Kit (QIAGEN, catalog number: 69506)

18. TaqMan $^{\mathrm{TM}}$ Universal PCR Master Mix (Thermo Fisher, catalog number: 4324018)

19. TaqMan Fast Advanced Master Mix (Thermo Fisher, catalog number: 4444557)

20. Platinum Taq DNA polymerase (Thermo Fisher, catalog number: 10966026)

21. Custom PCR primers and TaqMan probes, HPLC purified (Integrated DNA Technologies)

22. Turbo DNase (2 U/ul) (Thermo Fisher, catalog number: AM2238)

23. Dulbecco's Phosphate Buffered Saline (PBS) (Sigma, catalog number: D8537)

24. 10\% Fetal Bovine Serum (FBS) (Gibco, catalog number: 10438026)

25. Penicillin-Streptomycin (Gibco, catalog number: 15070063)

26. Dulbecco's Modified Eagle's Medium (DMEM) (Sigma, catalog number: D6171)

27. Absolute Ethanol (200 proof) (Fisher Scientific, catalog number: BP2818100)

28. Water (Sigma, catalog number: W4502)

29. $\mathrm{MgCl}_{2}$ (Thermo Fisher, catalog number: 10966026) (It comes in with the Platinum Taq DNA polymerase)

\section{Equipment}

1. $\quad 0.5-10 \mu l$ Eppendorf Research ${ }^{\circledR}$ plus Adjustable Volume Pipettes (Eppendorf, catalog number: 3123000020)

2. $10-100 \mu$ Eppendorf Research ${ }^{\circledR}$ plus Adjustable Volume Pipettes (Eppendorf, catalog number: 3123000047)

3. $20-200 \mu$ Eppendorf Research ${ }^{\circledR}$ plus Adjustable Volume Pipettes (Eppendorf, catalog number: 3123000055)

4. 100-1,000 $\mu$ l Eppendorf Research ${ }^{\circledR}$ plus Adjustable Volume Pipettes (Eppendorf, catalog number: 3123000063 )

5. Revco Laboratory $\mathrm{CO}_{2}$ Incubator Ultima II (Thermo Fisher, catalog number: RCO3000T9V)

6. Vortex-Genie 2 Vortex Mixer 12 (Scientific Industries, catalog number: 12-812)

7. NanoDrop ${ }^{\mathrm{TM}} 2000$ Spectrophotometer (Thermo Fisher, model: NanoDrop ${ }^{\mathrm{TM}}$ 2000, catalog number: ND-2000)

8. StepOnePlus ${ }^{\text {TM }}$ Real-Time PCR System (Thermo Fisher, catalog number: 4376600) 
9. Veriti ${ }^{\circledR}$ 96-Well Thermal Cycler (Thermo Fisher, catalog number: 4375786)

10. Eppendorf Centrifuge 5430R (Eppendorf, model: 5430R)

11. Eppendorf Centrifuge 5424R (Eppendorf, model: 5424R)

\section{Software}

1. StepOne software v2.2.2 (Thermo Fisher)

\section{Procedure}

A. VSV-G pseudotyped virus preparation and host cell infection

1. Culture $4 \times 10^{6} \mathrm{HEK} 293$ cells in DMEM with $10 \% \mathrm{FBS}$ and 100 units $/ \mathrm{ml}$ of penicillin and 100 $\mu \mathrm{g} / \mathrm{ml}$ of streptomycin in a $10 \mathrm{~cm}$ cell culture dish at $37^{\circ} \mathrm{C}, 5 \% \mathrm{CO}_{2}$ overnight.

2. In a $1.5 \mathrm{ml}$ Eppendorf tube, add $500 \mu \mathrm{l}$ of Opti-MEM ${ }^{\mathrm{TM}}$, and $25 \mu \mathrm{l}$ of X-tremeGENE 9 DNA Transfection Reagent (Roche), mix well by pipetting up and down gently, add $3 \mu \mathrm{g}$ of HIV-1 plasmids pNL4-3 env(-)nef(-)gfp(+) and $2 \mu \mathrm{g}$ of pVSV-G, mix gently by pipetting up and down. Leave at room temperature for $30 \mathrm{~min}$. Add to the cultured HEK293 cells drop by drop, and gently shake or swirl the dish to ensure distribution over the entire dish surface.

3. After $24 \mathrm{~h}$, wash the transfected HEK293 cells with PBS, and then replace it with $10 \mathrm{ml}$ fresh DMEM complete media.

4. After $48 \mathrm{~h}$ of transfection, harvest the supernatant containing pseudotyped viruses and pass through $0.45-\mu \mathrm{m}$-pore-size filters. The virus containing supernatant is then aliquoted and stored at $-80^{\circ} \mathrm{C}$.

5. Treat the prepared virus with $20 \mathrm{U} / \mathrm{ml}$ Turbo DNase at $37^{\circ} \mathrm{C}$ for $1 \mathrm{~h}$ before infection.

6. Prepare 0.5-0.75 × $10^{6}$ cells/well host cells for infection experiment in a 24-well plate. Differentiated human macrophages and THP1 cells, cultured adherent cell lines such as HCT116 are all suitable to be used as host cells. Add $100 \mu$ virus per well to cultured cells. After cells are infected for $2 \mathrm{~h}$ in the $37^{\circ} \mathrm{C}$ incubator, remove virus containing culture media, and replace it with fresh media.

7. At post infection time points as designed by experiment, remove culture media, and wash once with $0.5 \mathrm{ml}$ PBS. Discard all remaining PBS.

B. Extraction of total cellular DNA by using the DNeasy Blood \& Tissue Kit (QIAGEN)

1. To each well, add $200 \mu \mathrm{l} \mathrm{PBS}, 20 \mu \mathrm{l}$ Protease $\mathrm{K}$ and then $200 \mu \mathrm{l}$ Buffer AL. Mix thoroughly. Incubate the plate at $37^{\circ} \mathrm{C}$ for $5 \mathrm{~min}$ to lyse cells.

2. Transfer cell lysate into a $1.5 \mathrm{ml}$ Eppendorf tube. Incubate at $56{ }^{\circ} \mathrm{C}$ for $10 \mathrm{~min}$.

3. Add $200 \mu \mathrm{l}$ of $100 \%$ Ethanol to each sample, and mix thoroughly with a vortex mixer.

4. Pipet the mixture into the DNeasy Mini spin column placed into a $2 \mathrm{ml}$ collection tube. Centrifuge at $6,000 \times \mathrm{g}$ for $1 \mathrm{~min}$, using an Eppendorf Centrifuge 5424R. Discard flow-through and 
collection tube.

5. Place the DNeasy Mini spin column into a new $2 \mathrm{ml}$ collection tube, add $500 \mu \mathrm{l}$ Buffer AW1, and centrifuge for $1 \mathrm{~min}$ at 6,000 $\times \mathrm{g}$, using an Eppendorf Centrifuge 5424R. Discard flow-through and collection tube.

6. Place the DNeasy Mini spin column into a new $2 \mathrm{ml}$ collection tube, add $500 \mu \mathrm{l}$ Buffer AW2, and centrifuge for $3 \mathrm{~min}$ at 20,000 $\times \mathrm{g}$, using an Eppendorf Centrifuge 5424R. Discard flow-through and collection tube.

7. Place the DNeasy Mini spin column into a clean $1.5 \mathrm{ml}$ microcentrifuge tube, and pipet $100 \mu \mathrm{l}$ Buffer AE directly onto the DNeasy membrane without touching the tip to the membrane. Incubate at room temperature for $5 \mathrm{~min}$, and then use an Eppendorf Centrifuge 5424R to centrifuge for $1 \mathrm{~min}$ at 6,000 $\times \mathrm{g}$ to elute DNA.

8. Quantify DNA sample with a NanoDrop or similar device. Dilute DNA sample to $20 \mathrm{ng} / \mu \mathrm{l}$.

C. Quantification of HIV-1 reverse transcription products quantification

1. Prepare the reaction mix for each sample as follows: $1 \mu \mathrm{l}$ each of forward and reverse primers $(10 \mu \mathrm{M}), 1 \mu \mathrm{l}$ of TaqMan probe $(5 \mu \mathrm{M}), 5 \mu \mathrm{l}$ of DNA sample, $2 \mu \mathrm{l}$ of $\mathrm{H}_{2} \mathrm{O}$, and $10 \mu \mathrm{l} \mathrm{TaqMan}{ }^{\circledR}$ Universal PCR Master Mix (2x).

2. Calculate the volume of each component of the PCR reaction mix by multiplying the volume of each component by the number of replicates for each sample. Make a PCR master mix without sample DNA and prepare $110 \%$ of the required volume to account for pipetting error.

3. Pipet $15 \mu \mathrm{l}$ of PCR master mix to each reaction well, and add $5 \mu \mathrm{l}$ of sample DNA ( $20 \mathrm{ng} / \mu \mathrm{l})$. Seal the PCR Plate with film, and centrifuge it at 2,200 $\times \mathrm{g}$ for $30 \mathrm{~s}$, using an Eppendorf Centrifuge 5430R.

4. Perform PCR on a StepOnePlus ${ }^{\mathrm{TM}}$ Real-Time PCR System using the following program: $95^{\circ} \mathrm{C}$ 2 min preheat, then 40 cycles of $95^{\circ} \mathrm{C}$ for $15 \mathrm{~s}$ and $60^{\circ} \mathrm{C}$ for $1 \mathrm{~min}$.

5. When running a PCR that is quantifying HIV-1 early, intermediate, late reverse transcription products, as well as 2-LTR cycle DNA, it is necessary to use the GAPDH gene as a reference. In addition to this, the Real-time PCR should be carried out in parallel with target gene amplification.

6. Use Real-time PCR relative quantification $\triangle \Delta C$ t method to calculate sample target gene copy numbers.

D. HIV-1 integration quantification

1. DNA from Ach2 cells, which have a single copy HIV genome integration, is used as a copy number control. $3.59 \mu \mathrm{g}$ of genomic DNA contains about $10^{6}$ genome copies. Serially diluted DNA standards from $1 \times 10^{4}$ to 1 copies/ $\mu$ l (it is actually 1 copy) (20 ng DNA) are prepared by mixing DNA from Ach2 cells with DNA from uninfected human cells in corresponding proportions.

2. In the $1^{\text {st }}$ integration PCR, prepare a reaction with the following components: $2.5 \mu \mathrm{l} 10 \mathrm{x}$ buffer, $0.75 \mu \mathrm{l} 50 \mathrm{mM} \mathrm{MgCl} 2,0.5 \mu \mathrm{l} 10 \mathrm{mM}$ dNTP, $0.5 \mu \mathrm{l}$ of each forward and reverse Alu primers 
$(10 \mu \mathrm{M}), 0.5 \mu \mathrm{l}$ reverse primer HIV-1 gag-R $(10 \mu \mathrm{M}), 0.5 \mathrm{U}$ of Platinum Taq DNA polymerase (Thermo Fisher), $5 \mu \mathrm{l}$ sample DNA (100 ng), add $\mathrm{H}_{2} \mathrm{O}$ to total $25 \mu \mathrm{l}$. Perform PCR using a Veriti ${ }^{\circledR}$ 96-Well Thermal Cycler (Thermo Fisher) with the following program: preheat to $94{ }^{\circ} \mathrm{C}$ for $2 \mathrm{~min}$, then run 15 cycles of $94{ }^{\circ} \mathrm{C}$ for $30 \mathrm{~s}, 55^{\circ} \mathrm{C}$ for $30 \mathrm{~s}, 72^{\circ} \mathrm{C}$ for 3 min. Hold the samples at $72{ }^{\circ} \mathrm{C}$ for additional $5 \mathrm{~min}$.

3. For the $2^{\text {nd }}$ round of Real-time PCR for integration quantification, prepare the reaction mix for each sample as follows: $1 \mu \mathrm{l}$ each of forward and reverse primers $(10 \mu \mathrm{M}), 1 \mu \mathrm{l}$ of TaqMan probe $(5 \mu \mathrm{M}), 5 \mu \mathrm{l}$ of 10 -fold diluted $1^{\text {st }}$ round PCR product, $2 \mu \mathrm{l}$ of $\mathrm{H}_{2} \mathrm{O}$, and $10 \mu \mathrm{l} \mathrm{TaqMan}{ }^{\circledR}$ Universal PCR Master Mix (2x).

4. Perform $P C R$ with StepOnePlust ${ }^{\mathrm{TM}}$ Real-time $\mathrm{PCR}$ System using the following program: Preheat to $95^{\circ} \mathrm{C}$ for $2 \mathrm{~min}$, then 40 cycles of $95^{\circ} \mathrm{C}$ for $15 \mathrm{~s}$, and $60^{\circ} \mathrm{C}$ for $1 \mathrm{~min}$.

5. Use the Real-time PCR standard curve method to determine sample target gene copy numbers.

6. Representative experiments can be found in Figure 2 of paper by Shi et al. (2018) and Figure 7 of paper by Furuya et al. (2016).

\section{$\underline{\text { Notes }}$}

1. The PCR primers and TaqMan probes are designed based on HIV-1 sequence of pNL4-3. Please check sequence alignment if other strains of HIV-1 viruses are used.

2. If uses HIV-1 isolates or lab strains, DNase treatment is not necessary.

3. Another Real-time PCR reagent, TaqMan Fast Advanced Master Mix (Thermo Fisher), has provided results similar to $\operatorname{TaqMan}^{\circledR}$ Universal PCR Master Mix (Thermo Fisher).

\section{Acknowledgments}

This study was supported by the Scholarship of Discovery Intramural Research Grant to Dr. Binshan Shi by Albany College of Pharmacy and Health Sciences; Protocols described here were adapted from protocols from previous publications by Butler et al., 2001; Yamamoto et al., 2006; Mbisa et al., 2009.

\section{Competing interests}

All authors declare no conflicts of interest or competing interests.

\section{References}

1. Hu, W. S. and Hughes, S. H. (2012). HIV-1 reverse transcription. Cold Spring Harb Perspect Med 2(10).

2. Sloan, R. D. and Wainberg, M. A. (2011). The role of unintegrated DNA in HIV infection. 
Retrovirology 8(1): 52.

3. Zheng, Y. H., Jeang, K. T. and Tokunaga, K. (2012). Host restriction factors in retroviral infection: promises in virus-host interaction. Retrovirology 9: 112.

4. Shi, B., Sharifi, H. J., DiGrigoli, S., Kinnetz, M., Mellon, K., Hu, W. and de Noronha, C. M. C. (2018). Inhibition of HIV early replication by the p53 and its downstream gene p21. Virol J 15(1): 53.

5. Furuya, A. K., Sharifi, H. J., Jellinger, R. M., Cristofano, P., Shi, B. and de Noronha, C. M. (2016). Sulforaphane inhibits HIV Infection of macrophages through Nrf2. PLoS Pathog 12(4): e1005581.

6. Butler, S. L., Hansen, M. S. T. and Bushman, F. D. (2001). A quantitative assay for HIV DNA integration in vivo. Nature Medicine 7: 631.

7. Yamamoto, N., Tanaka, C., Wu, Y., Chang, M. O., Inagaki, Y., Saito, Y., Naito, T., Ogasawara, H., Sekigawa, I. and Hayashida, Y. (2006). Analysis of human immunodeficiency virus type 1 integration by using a specific, sensitive and quantitative assay based on Real-time polymerase chain reaction. Virus Genes 32(1): 105-113.

8. Mbisa, J. L., Delviks-Frankenberry, K. A., Thomas, J. A., Gorelick, R. J. and Pathak, V. K. (2009). Real-time PCR analysis of HIV-1 replication post-entry events. Methods Mol Biol 485: 55-72. 